\title{
Kronik Prostatit/Kronik Pelvik Ağrı Sendromu: Güncelleme
}

\author{
Mete Çek $^{1}$
}

${ }^{1}$ Trakya Üniversitesi, Tıp Fakültesi, Üroloji Anabilim Dalı, Edirne

\section{Giriş}

"Kronik prostatit/Kronik pelvik ağrı sendromu" adıyla bilinen klinik tablo, \%8.2 (\%2.2-9.7) prevalansı ile toplumda iskemik kalp hastalığı ve diyabet kadar yaygın olan bir durumdur (1). Erkeklerde, -böbrekler dâhil olsun ya da olmasın- febril idrar yolları enfeksiyonlarının \%10 kadarında prostatın da enfeksiyon sürecine katıldığı gösterilmiştir. Prostatit tablolarının birbirine dönüşme özelliği vardır; özellikle akut bakteriyel prostatit hastalarının \%10 kadarında kronik bakteriyel prostatit gelişmesi, yine kronik bakteriyel prostatit hastalarının yaklaşık \%10'unda kronik pelvik ağrı sendromuna dönüşüm olması; hem hastalar hem de hekimler açısından tedavi başarısını etkileyen özelliklerdir.

Akut, kronik prostatit ve prostatodini alt grup adlarıyla bilinen ve tarihsel süreç içinde çok iyi anlaşılıp incelenemeyen tablolar, 1999 yılında Amerikan Ulusal Sağlık Kurumu (NIH) tarafından önerilen yani sınıflandırmanın kabul edilmesiyle 1) enfeksiyöz formlar, 2) kronik pelvik ağrı sendromu ve 3) asemptomatik prostatit olarak başlıca üç gruba ayrılmıştır (2). Bu yeni sınıflandırma ve her bir kategorinin eski sınıflandırmada karşılık geldiği durum ve tanı kriterleri Tablo 1'de gösterilmiştir. Bu yeni sınıflandırma, hem hastaların ilk değerlendirmesini önceden tanımlanmış standart formlara sokması, hem de tedavi sonuçlarının karşılaştırılmasına yardımcı olması bakımından araştırmacılar için çok yararlı olmuştur.

Öte yandan, yine 1999 yılında NIH tarafından kronik pelvik ağrı semptom indeksinin (NIH-CPSI) yayınlanması ve yaygın kabul görmesiyle, bu alanda yapılan çalışmaların sonuçlarının ve tedavi başarısının ölçülebilir olması yönünde önemli bir adım atılmış; bu tarihten itibaren "Kronik prostatit/Kronik pelvik ağrı sendromu" konusunda yapılan ve yayınlanan çalışmaların sayısı hızla artmaya başlamıştır (3). NIH-CPSI üç ayrı alandaki (ağrı, üriner semptomlar ve yaşam kalitesi) semptomların varlığ ve şiddetini dokuz soruyla sorgulayarak skorlayan bir semptom indeksidir. Ayrıntıları Tablo 2' de gösterilmiştir. Tedavi sonuçları değerlendirilirken genellikle başlangıçtaki toplam skordan tedavi sonrası 6 puanlık bir azalma olması, 'pozitif tedavi yanıtı' olarak kabul edilmektedir.

Ayrıca her bir semptom alanındaki değişim ve iyileşmeler de tek tek değerlendirilebilir. Klinik bulguların gerek göstermesi durumunda "Uluslararası Prostat Semptom Skoru" ve "Uluslararası Erektil Fonksiyon İndeksi" de değerlendirmeye katılabilir.

Bu yazıda, akut ve kronik bakteriyel prostatite kısaca değinilerek "Kronik prostatit/Kronik pelvik ağrı sendromu" konusunda yukarıda özetlenen gelişmelerin ışı̆̆ında son yıllarda yaşanan gelişmelerin güncellenmesi amaçlanmiştır.

Tablo 1: Kronik prostatit/Kronik pelvik ağrı sınıflandırması

Kronik prostatit/Kronik Pelvik Ağrı Sınıflandırması (Eski sinıflandırma)

I. Akut bakteriyel prostatit

II. Kronik bakteriyel prostatit

III. Kronik nonbakteriyel prostatit

IIIa. Enflamatuar

IIIb. Nonenflamatuar

IV. Asemptomatik enflamatuar

prostatit (Histolojik prostatit)
(Akut bakteriyel prostatit)

(Kronik bakteriyel prostatit)

(Nonbakteriyel prostatit)

(Prostatodini)

(Yok)

Hastaların incelenmesi: Öykünün ardından yapılan fizik muayenede rutin olarak karın, genita bölge, perine ve prostat incelenmelidir. Bu muayene sirasinda "myofascial trigger noktalar" ve/ya da pelvisin kas iskelet disfonksiyonunun değerlendirilmesi yararlı olur. Daha sonra semptomlar, yukarıda sözü edilen NIH skorlamasına göre değerlendirilmelidir. İdrar tahlili ve idrar kültürü de hastaların ilk değerlendirilmesinde mutlaka yapılması gerekenler listesindedir. Opsiyonel olan incelemeler ise enfeksiyonun lokalizasyonu, idrar akım hızı, rezidüel idrarın belirlenmesi ve transrektal ultrasonografidir. Ancak dört kadeh testinin yerini iki kadeh testinin aynı güvenilirlikle alması nedeniyle, enfeksiyon lokalizasyonunun da ilk aşamada yapılması daha uygun olacaktır. Prostat kanseri riski/şiphesi olan hastalar dışında PSA incelemesi KP/KPAS hastalarında gerekli değildir. Transrektal ultrasonografi tanıda yararlı değildir; ancak ayırıcı tanıda prostat absesi, kalsifikasyon, vesicula seminalis dilatasyonu gibi anatomik değişikliklerle birlikte olan durumlar düşünülüyorsa yapılmalıdır (4).

\section{Enfeksiyöz Prostatit Formları}

\section{Akut bakteriyel prostatit (Kategori I Prostatit- KIP)}

Akut bakteriyel prostatit, ortaya çıkışı bakımından gürültülü bir tablo oluşturmakla birlikte, genellikle uygun antibiyotik tedavisine yanıt veren bir prostatit kategorisidir. Neden olan mikroorganizmalar içinde E. Coli, \%65-80'lere varan sıklıktadır. Halsizlik, ateş, üşüme-titreme ve terleme 
Tablo 2: NIH-CPSI (Amerikan Sağlık Enstitüsü Kronik Prostatit Semptom İndeksi)

\title{
AMERIKAN ULUSAL SAĞLIK ENSTITÜSÖ KRONIK PROSTATIT SEMPTOM INDEKSI
}

\author{
(National Institutes of Health-Chronic Prostatitis Symptom Index-NIH-CPSI)
}

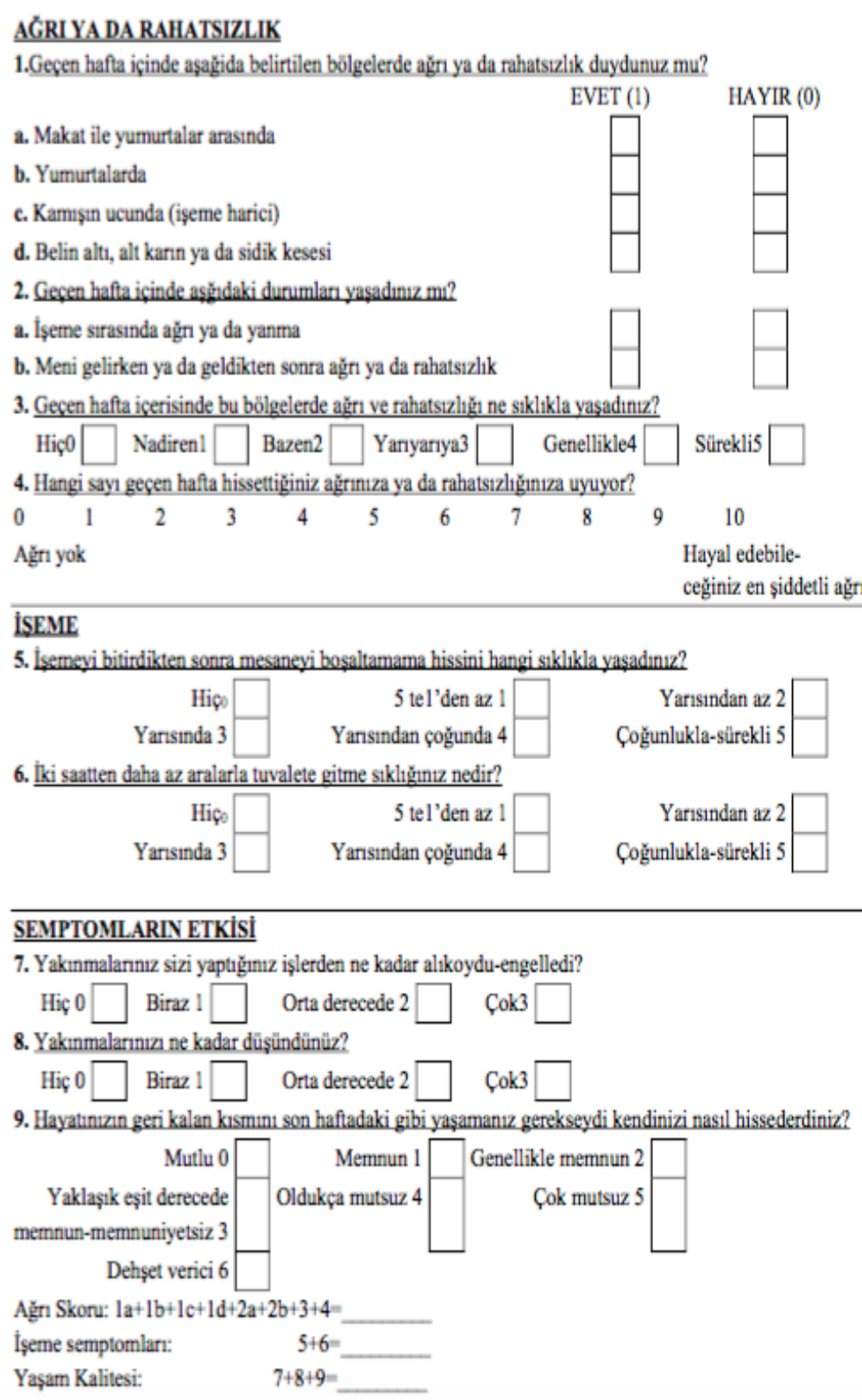

gibi sistemik bulgulara dizüri, pollaküri, sıkışma gibi üriner, perineal ağrı gibi yerel belirtiler eşlik eder. Parmakla rektal inceleme sırasında fazla basınç uygulanması tabloyu ağırlaştırabilir, bu açıdan dikkatli olunmalıdır. İnceleme sırasında prostatın duyarlı olduğu kolayca fark edilebilir.

Tedavide 2-4 haftalık oral antibiyotik tedavisi (florokinolon, TMP-SMX) önerilir; ancak antibiyotiklerin önerilen süre boyunca kullanılarak tedavinin tamamlanmasına dikkat edilmelidir.
Yeni gelişmeler: Prostat kanseri'nin tanınması amacıyla prostatın görüntülenmesindeki gelişmelerle birlikte; prostatitli hastalarda da multiparametrik MRI gibi bu yeni yöntemler değerlendirilmeye başlanmıştır (5). Akut prostatitte T2W1'de düşük sinyal intansitesi (SI) ve kısıtlı difüzyon özelliği ön plandadır, ancak prostat kanseri ile örtüşen "enhancement" paternleri de görülebildiği için prostat absesi dışında ayırıcı tanıda klinik bulgular dikkate alınmalıdır. Yine pozitron emisyon tomografi ile Kategori I prostatitin 
rezolüsyonunun değerlendirilmesi mümkün olabilmektedir.

Önemli bir nokta da transrektal prostat biyopsisi sonrası gelişen kategori I prostatite neden olan E. Colilerde yüksek oranda direncin bulunmasıdır. Bu hastalarda genellikle IV 3. Kuşak sefalosporin ve imipenem bile etkin bir tedavi sağlayamayabilmektedir (6).

\section{Kronik bakteriyel prostatit (Kategori II Prostatit- KIIP)}

Erkeklerde özellikle aynı etkene bağlı yineleyen üriner enfeksiyonlar, kronik bakteriyel prostatiti akla getirmelidir. $\mathrm{Bu}$ kategoride tanının başlıca anahtarı iki kadeh testidir. Semen ya da ejakülat kültürlerinde daha fazla mikroorganizma ortaya çıkartılabilir; ancak aksesuar glandlardan ya da kontaminasyonla gelen mikroorganizmalar nedeniyle bu örnekler, kronik bakteriyel prostatit tanısında değerli değildir.

Tedavi: İki ile dört haftalık antibiyotik uygulaması, kılavuzların yaygın olarak kabul ettiği bir protokoldür. Ancak kronik prostatit tedavisinde antibiyotiklerin prostat dokusuna geçişi önemlidir. Kinolonlar, sulfonamidler, makrolidler ve tetrasiklinler gibi pKa değeri ya da lipid çözünürlüğü yüksek olan antibiyotikler prostat dokusuna daha yüksek oranda nüfuz eder.

Gelişmeler: Hızlı tanı koyabilmek amacıyla prostat sıv1sında lökosit CD64 ekspresyonunun araştırılmasının bakteri kültürlerine göre daha avantajlı olabileceği gösterilmiştir (7). Yine semptom şiddeti yüksek olan ve tedaviden daha az yararlanan hastalardaki etken bakterilerin daha fazla biyofilm oluşturduğu saptanmıştır (8). Seminal keselerde yerleşen bakterilerin yineleyen kronik prostatite neden olabileceği de yapılan araştırmalarla ortaya konulmuştur (9). Fosfomisinin normal prostat dokusunda yeterli konsantrasyonlara eriştiğinin saptanması da bu ilacın dirençli kronik bakteriyel prostatitlerde bir tedavi seçeneği olabileceğini göstermektedir (10).

\section{Nonenfeksiyöz prostatit formları}

Nonenfeksiyöz formlar, kronik prostatit/kronik pelvik ağrı sendromlu hastaların \%80'inde görülmektedir. Güncel sinıflandırmada nonenfeksiyöz formlar enflamatuar ve nonenflamatuar olarak iki alt gruba ayrılmaktadır.

Yapılan randomize kontrollü çalışmalar (RKÇ) ile pek çok ajan ya da tedavi yönteminin etkinliği araştırılmıştır. Bu çalışmalar, nispeten küçük çaplı ve seçilmiş hasta gruplarında etkin görünen pek çok ajan ya da tedavi yöntemi için yeterli kanıta ulaşamamıştır. Magistro ve ark.'ları, 28 randomize kontrollü çalışmayı değerlendirdikleri çalışmalarında monoterapinin etkili olduğu bir seçenek bulunmadığını bildirmişlerdir (11). Kısaca özetlemek gerekirse, antibiyotiklerin ya da $\alpha$-blokerlerin bu grup hastada primer tedavi seçeneği olması RKÇ tarafından desteklenmemektedir. Ancak $\alpha$-blokerlerin çoklu tedavinin bir parçası olabileceği kabul edilmektedir. Yine antienflamatuar ya da immün modüler ilaçların monoterapide etkili olmadığı; hormonal ilaçların da bu grup hastalara primer tedavi seçeneği olarak önerilemeyeceği bildirilmiştir. Öte yandan pregabalin, nörolojik yan etkileri nedeniyle tek başına ilk tedavi olarak önerilmezken; quercetin, cernilton gibi bazı fitoterapötik ajanların tekli ya da çoklu tedavilerde yararlı olabileceği gösterilmiştir (11). Bunun yanında, Pentozan polisülfat'ın tek başına ilk tedavi ajanı olamayacağı ve bu gruptaki bazı hastaların fizyoterapiden yararlanabileceği rapor edilmiştir (perineal ESWL, akupunktur, aerobik egzersiz) (11).

Alexander ve ark.'ları, siproflokasisin 500x2/gün, tamsulosin $0.4 \mathrm{mgx} 4 /$ gün ya da kombinasyonunun altı haftalık uygulamasının plasebodan iyi olmadığını gösterirlerken, Tuğcu ve ark.'ları ise doksazosin $4 \mathrm{mgx}$ /gün; üçlü tedavi (doxazosin 4 mgx4/gün ibuprofen 400 mgx4/gün, thiocolchicoside (12 mgx4/gün) ile plasebonun altı aylık uygulamasını karşılaştırdıkları çalışmalarında tekli tedavinin de üçlü tedavinin de plasebodan daha iyi sonuç verdiğini bildirmişlerdir $(12,13)$.

\section{Fenotipik yönlendirme ile tedavi}

Kronik prostatit/Kronik pelvik ağrı sendromu (KP/KPSS) tedavisinde tekli tedavilerin etkinliğinin sınırlı kalması, buna karşılık çoklu tedavilerin daha başarılı bulunması, araştırmacıların bu tabloyu ortaya çıkaran değişik fenotipik özelliklerin bulunduğunu düşünmesine yol açmıştır. Bu farklı fenotipik özellikleri altı grup halinde toplayan Shoskes ve ark.'ları da UPOINT olarak tanımladıkları yeni bir tanımlamayı ve buna bağlı tedavi şemalarını ortaya atmıştır (14). Burada " $U$ " üriner semptomlarl, " $\mathrm{P}$ ” psikososyal belirtileri, “ $\mathrm{O}$ ” organa, yani prostata özgü belirtileri, "I" enfeksiyonu, "N" nörojenik ya da sistemik yakınmaları, " $\mathrm{T}$ " ise özellikle pelvik tabanda duyarlılığı göstermektedir. Shoskes'in bu sınıflandırmayı esas alan ilk çalışmasında en az üç alanda bulgusu olan 100 erkek hastaya multimodal tedavi uygulanarak hastalar 50 hafta izlenmiş, bu süre sonunda hastaların \%84'ünde total NIH-CPSI skorunda en az 6 puan düşüş, Tüm NIH-CPSI alt gruplarında düzelme olduğu belirlenmiştir (15).

Daha sonra bu alanlara cinsel disfonksiyonun da eklenmesi önerilerek UPOINTs olarak adlandırılmış ve ilk çalış-

Tablo 3: Fenotipik özelliklere göre tedavinin düzenlenmesi

\begin{tabular}{lll}
\hline Tanı (CP/CPPS) & Bulgular & Tedavi \\
\hline $\mathrm{U}$ & İdrar akımında zayıflama & Alfa bloker \\
$\mathrm{P}$ & Depresyon & Psikolojik destek, trisiklik antidepresanlar \\
$\mathrm{O}$ & Palpasyonla duyarlılık, perinede rahatsızlık hissi, & Polen ekstresi, quercetin \\
& Sicaklık hissi & \\
$\mathrm{I}$ & (Enfeksiyon) Geçirilmiş enfeksiyon, pozitif kültür & Antibiyotik \\
$\mathrm{N}$ & Nöropatik ağrı & Pregabalin, trisiklik antidepresanlar, akupunktur \\
$\mathrm{T}$ & Perineal/pelvik kas duyarlılı̆̆ 1 & Lokal sıcak, fizyoterapi/pelvik taban gevşetme \\
$\mathrm{S}$ & (Erektil disfonksiyon) & ED tedavisi \\
\hline
\end{tabular}


malar KP/KPSS semptomlarına ek olarak cinsel disfonksiyon yakınması olan hastalarda da; multimodal tedavinin semptomların düzelmesi ve yaşam kalitesinin iyileştirilmesi açısından başarılı olduğunu göstermiştir.

$\mathrm{KP} / \mathrm{KPSS}$ hastalarında etken bir mikroorganizmanın bulunabileceği, ancak bunun şimdiye dek gösterilemediği düşüncesi ile üriner mikrobiom araştırılması çalışmaları da başlamıştır. Shoskes ve ark.'ları, bu hasta grubunun idrar örneklerindeki mikrobiyomu asemptomatik ya da yalnızca üriner enfeksiyonu olan hastalardakiyle karşılaştırmışlardir. İlk bulgular, KP/KPAS grubunda özellikle daha yüksek Clostridium bulunduğunu ve bunun tedavide hedefe yönelik uygulamalar sağlayabileceği yönündedir (16).

Yeni gelişmeler: Prostat spesifik antijenin prostat epitelyum hücrelerini Echerichia coli invazyonuna karşı önlediği, in vitro çalışmalarda gösterilmiştir. Ayrıca, PSA negatif olup PSA ile inkübe edilen hücrelerde de bu invazyona karşı direnç gelişmesi, bakteriyel prostatit gelişiminin PSA ile ilişikili olabileceğini göstermektedir (17).

\section{Nasıl tedavi edelim?}

Yukarıda anlatılanlar ışı̆̆ında KP/KPAS olan hastalarda aşağıdaki tabloda verilen ve fenotipik özellikleri göz önüne alan tedavi seçenekleri öncelikle denenebilir (Tablo 3).

\section{Sonuç}

Kronik prostatit ve kronik pelvik ağrı sendromunun değişik alt grupları hakkında yapılan çeşitli çalışmalar, tedavi yöntemleri konusunda net ve yüksek düzeyde kanıtı olan bilgiler verememektedir. Bu çalışmaların değerlendirildiği ayrıntılı literatür taramaları ya da meta analizler bile önerileri uzman görüşü ile kombine ederek vermeyi yeğlemektedir. Bunun da temel nedeni KP/KPAS fizyopatolojisinin halen tam olanak anlaşılamamış olmasıdır. Tedavi hedefleri net değildir; tedavisi halen çok güçtür. Özellikle monoterapiler için yüksek düzeyde kanıt yokluğu, en etkin yaklaşım olarak multimodal tedavi yaklaşımını öne çıkarmaktadır.

\section{Kaynaklar}

1. Epidemiology of prostatitis. Krieger JN, Lee SW, Jeon J et al. Int J Antimicrob Agents. 2008; Suppl 1: S85-90.

2. Krieger JN, Nyberg L Jr, Nickel JC. NIH consensus definition and classification of prostatitis. JAMA 1999; 282: 236-7.

3. Litwin MS, McNaughton-Collins M, Fowler FJ, Jr, Nickel JC, Calhoun EA, Pontari MA, et al. The National Institutes of Health chronic prostatitis symptom index: development and validation of a new outcome measure. J Urol. 1999;162:369-75.

4. Schaeffer, A.J. Epidemiology and evaluation of chronic pelvic pain syndrome in men. Int J Antimicrob Agents 2008; Suppl 1: S108-111.

5. Gill BC, Shoskes DA, Bacterial prostatitis. Curr Opin Infect Dis. 2016; 29: 86-91.
6. Campeggi A, Ouzaid I, Xylinas E et al. Acute bacterial prostatitis after transrectal ultrasound-guided prostate biopsy: epidemiological, bacteria and treatment patterns from a 4-year prospective study. Int J Urol. 2014 21: 1525.

7. Qian L, Li SB, Zhou Y et al. Determination of CD64 for the Diagnosis of Bacterial Chronic Prostatitis. Am J Reprod Immunol. 2015; 74: 309-12.

8. Bartoletti R, Cai T, Nesi Get al. The impact of biofilmproducing bacteria on chronic bacterial prostatitis treatment: results from a longitudinal cohort study. World J Urol. 2014; 32: 737-42.

9. Park SH, Ryu JK, Choo GY et al. Chronic bacterial seminal vesiculitis as a potential disease entity in men with chronic prostatitis. Int J Urol. 2015; 22: 508-12.

10. Grayson ML, Macesic N, Trevillyan et al Fosfomycin for Treatment of Prostatitis: New Tricks for Old Dogs. Clin Infect Dis. 2015; 61: 1141-3.

11. Magistro G, Wagenlehner FME, Grabe M. Et al. Contemporary Management of Chronic Prostatitis/ Chroniz Pelvic Pain Syndrome. Eur Urol 2016; 69: 286297.

12. Alexander RB, Propert KJ, Schaeffer AJ et al. Ciprofloxacin or tamsulosin in men with chronic prostatitis/chronic pelvic pain syndrome: a randomized, double-blind trial. Chronic Prostatitis Collaborative Research Network. Ann Intern Med. 2004; 141: 581-9.

13. Tuğcu V, Taşçi AI, Fazlioğlu A et al. A placebo-controlled comparison of the efficiency of triple- and monotherapy in category III B chronic pelvic pain syndrome (CPPS). Eur Urol. 2007 51: 1113-7.

14. D.A. Shoskes, J.C. Nickel, R. Dolinga, D. Prots. Clinical phenotyping of patients with chronic prostatitis/chronic pelvic pain syndrome and correlation with symptom severity. Urology 2009; 73: 538-542.

15. Shoskes DA, Nickel JC, Kattan MW. Phenotypically directed multimodal therapy for chronic prostatitis/ chronic pelvic pain syndrome: a prospective study using UPOINT. Urology 2010; 75:1249-53.

16. Daniel A. Shoskes, Jessica Altemus, Alan S. Polackwich et. al. The Urinary Microbiome Differs Significantly Between Patients With Chronic Prostatitis/Chronic Pelvic Pain Syndrome and Controls as Well as Between Patients With Different Clinical Phenotypes. Urology 92: 26-32, 2016.

17. Townes CL, Ali A., Gross N. Et al., Prostate specific antigene enhances the innate defence of prostatic epithelium against Echerichia coli infection. Prostate 2013; 73: 1529-1537.

\section{Yazışma Adresi:}

Mete Çek,

Trakya Üniversitesi, Tıp Fakültesi, Üroloji Anabilim Dall, Edirne Tel: +90 5322626032

e-mail:cekmd@doruk.net.tr 